\title{
Anabases
}

ANABASES Traditions et réceptions de l'Antiquité

$15 \mid 2012$

Varia

\section{Traditions allemandes des sciences de l'Antiquité : entretien avec Wilfried Nippel}

\section{Wilfried Nippel}

\section{(2) OpenEdition}

\section{Journals}

Édition électronique

URL : http://journals.openedition.org/anabases/3791

DOI : 10.4000/anabases.3791

ISSN : 2256-9421

\section{Éditeur}

E.R.A.S.M.E.

\section{Édition imprimée}

Date de publication : 1 avril 2012

Pagination : 185-207

ISSN : 1774-4296

\section{Référence électronique}

Wilfried Nippel, «Traditions allemandes des sciences de l'Antiquité : entretien avec Wilfried Nippel »,

Anabases [En ligne], 15 | 2012, mis en ligne le 01 avril 2015, consulté le 21 octobre 2019. URL : http:// journals.openedition.org/anabases/3791 ; DOI : 10.4000/anabases.3791 


\section{Traditions allemandes des sciences de l'Antiquité : entretien avec Wilfried Nippel}

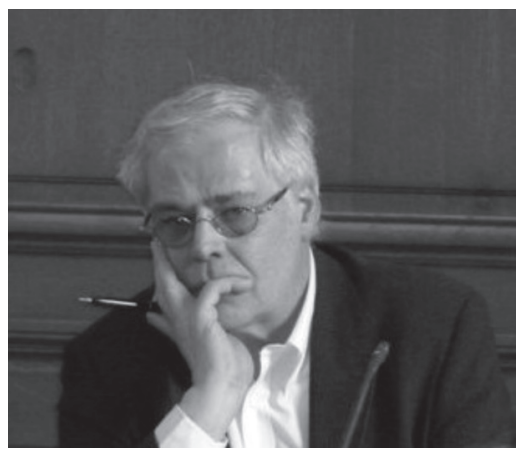

LE MARDI 6 AVRIL 2011, l'équipe PLH-ERASME recevait Wilfried NIPPEL pour un long échange autour de son parcours en Histoire ancienne, ses intérêts pour l'Historiographie et la Réception de l'Antiquité, les perspectives dans ces domaines, ses projets, etc. Hinnerk Bruhns (Directeur de recherche émérite du CNRS et membre du Comité Scientifique d'Anabases) nous fit l'amitié de se joindre à nous pour discuter avec un ami de longue date.

Après des études d'histoire et de Germanistik à Cologne et Marburg, et un doctorat à Bochum, Wilfried Nippel a effectué un séjour de recherche en Angleterre, tout en préparant son habilitation, soutenue à Munich en 1983. Il commença sa carrière à Bielefeld (1983-1992) et la poursuit depuis 1992 à l'université Humboldt de Berlin. Il est membre de l'Académie de Berlin-Brandenburg depuis 1997.

Sa bibliographie est considérable et très originale dans le panorama des sciences de l'Antiquité. Des thématiques fortes s'en dégagent: l'histoire constitutionnelle, l'histoire des idées politiques, mais aussi l'histoire culturelle, la théorie ou la philosophie de l'histoire (Geschichtsschreibung), avec en particulier des travaux sur Gibbon, Mommsen et Momigliano, la réception de l'Antiquité, les études weberiennes, sans oublier ses travaux autour du thème de la sécurité, l'ordre public, la police. Plusieurs de ces orientations se retrouvent dans son dernier ouvrage, Liberté antique, liberté moderne. Les fondements de la démocratie de l'Antiquité à nos jours (Toulouse, PUM, 2010 ; éd. or. all. 2008), 
qui aborde la question de la place que joue encore et toujours le modèle athénien dans les débats de l'époque moderne et contemporaine sur la démocratie.

Dans la production de W. Nippel, le recours à des outils anthropologiques et sociologiques est très sensible. Il lui permet d'appréhender les sources antiques à travers des questionnements renouvelés et par le truchement de concepts récents. C'est une des clés de la fécondité et de l'originalité de ses travaux. Membre du comité scientifique d'Anabases, il a discuté avec nous à bâtons rompus des sujets qui nourrissent la revue.

La transcription de cet échange, très fidèle à la version orale, a été assurée par Anthony Andurand (docteur de l'université de Toulouse, PLH-ERASME) et revue par Wilfried Nippel. À l'un et à l'autre va notre gratitude. Ce "morceau d'anthologie "s'ajoute à d'autres pièces du même genre : l'entretien avec Luciano Canfora (paru dans Anabases 1), celui avec Claude Mossé (Anabases 7), celui avec Oleg Grabar (Anabases 11) et le dernier paru, l'échange avec Maurice Sartre (Anabases 13). D'autres suivront, pour le plus grand plaisir de nos lecteurs, nous l'espérons...

Corinne Bonnet : Aujourd'hui encore, en Allemagne mais aussi en France, quand on parle de "sciences de l'Antiquité ", on ne peut s'empêcher d'évoquer le nom de Mommsen, personnage auquel vous avez consacré bon nombre de publications, notamment sur son Staatsrecht. L'intérêt que vous portez à l'histoire constitutionnelle s'inscrit-il consciemment dans une tradition mommsenienne ? Est-ce là, par ailleurs, une caractéristique qui vous est propre, ou bien existe-t-il aujourd'hui encore en Allemagne une tradition d'études qui se revendique des travaux de Mommsen ?

Wilfried Nippel : It's difficult to answer... Modern constitutional history has tried to move away from Mommsen's Staatsrecht and its strong systematic approach. My book on the late Roman Republic is not written in a "Mommsen-style" Staatsrecht tradition. I have grown up in an atmosphere in ancient history in which everybody working on Roman history said: "We have to get rid of Mommsen's rigid approach."

When I wrote a paper ${ }^{1}$ on Mommsen's Staatsrecht, on the occasion of a conference held in 2003, I had two insights. First of all, that since Mommsen everybody tried to overcome him and nobody achieved it! Momigliano once said that somebody who wants to replace Mommsen should be a greater scholar than Mommsen. There is more in Mommsen than this systematic approach. I would say: "Always read the footnotes and then you will see this tension between the systematic and the historical approach."

1 W. Nippel, "Das "Staatsrecht" in der Diskussion. Von 1871 bis heute ", in W. Nippel, B. Seidensticker (Hg.), Theodor Mommsens langer Schatten. Das römische Staatsrecht als bleibende Herausforderung für die Forschung, Hildesheim, Olms Verlag, 2005, p. 9-60. 
There's another point. We have now all those scholars who proclaim: "We have to reconstruct the political culture of the late Republic." With all modesty, I think that some of these aspects are already dealt with in Aufrubr und "Polizei" in der römischen $R_{e p u b l i k}{ }^{2}$. I don't say it was a totally new approach, but I think I just stressed the symbolic dimensions of Roman politics without great ado. There is an ongoing discussion on the symbolic aspects of election and the applicability of the concept clientela and so on, but there are still some questions which cannot really be answered without Staatsrecht. For example: has every voter two votes at consular elections? If one candidate is already elected and the election is going on, what will happen with the second vote? I think we cannot answer the question, but then all our constructions on bargaining with votes, on the idea of some voters being bound to one candidate and "free" for another, etc. have no secure basis. Being older now, I appreciate Mommsen more than I did in the past. And, in more general terms, I stand in the German tradition of Staatsrecht and Verfassungsgeschichte (not only with regard to Antiquity) which in my view should be supplemented by a history of political culture but cannot be replaced by it.

Corinne Bonnet : Une seconde question. Une des caractéristiques qui me frappe dans vos ouvrages comme dans les réponses que vous venez de formuler - et c'est une caractéristique allemande -, c'est celle d'avoir des chaires qui sont des chaires d'" histoire ancienne ", associant la Grèce et Rome. Comment est-ce possible de dominer deux domaines qui sont aussi gigantesques, faisant chacun appel à une vaste bibliographie ? Qu'est-ce qui justifie ce choix ? Vous faites sans doute figure d'exception, car vous possédez une érudition hors du commun ; mais comment font vos collègues allemands? Si l'on compare avec ce qui se fait ici, en France, ou ailleurs, où l'on a des professeurs d'histoire grecque ou romaine, le fait de continuer de travailler sur les deux domaines à la fois est-il vraiment fructueux ? Cela donne-t-il vraiment lieu à des comparaisons? Quelles sont, selon vous, les raisons de ce choix de politique universitaire?

Wilfried Nippel : That is a general phenomenon. In most cases, younger scholars are advised that someone who has written a doctoral dissertation on a Roman subject should move to Greek history or the other way round. I think it depends on the fact that at smaller universities there is just one chair for ancient history, so that it's a reasonable career strategy to do both. Second point: in his contribution ${ }^{3}$ to $L a$ fin de

2 W. Nippel, Aufruhr und "Polizei " in der römischen Republik, Stuttgart, Klett-Cotta, 1988 (Hab.) ; voir aussi Public Order in Ancient Rome, Cambridge, Cambridge University Press, 1995.

3 H. BRUHNS, "Les institutions et les réseaux ou comment des traditions nationales se construisent sur un objet commun. Éléments pour une comparaison des institutions scientifiques françaises et allemandes en histoire ancienne ", in H. BRUHNS, J.-M. DAVID, 
la République romaine, dedicated to the institutional backgrounds of career structures in France, Hinnerk Bruhns - that is one of the points I remember quite well - insisted on the dominating role of the two "écoles" (the École française de Rome and the École française d'Athènes), where obviously most younger scholars start their career: that also implies a strong connection between ancient history and archaeology. In the German case that applies only to a minority. Our "broader" range with respect to Greece and Rome is counterbalanced by our "narrower" approach, based on history in a more traditional sense, and not with a strong connection with archaeology or with other disciplines.

I think it's not that difficult to study both Greece and Rome. Why should it be so?

Hinnerk Bruhns : Ce sont là deux domaines, pourrait-on d'ailleurs ajouter, qui ne forment qu'un seul monde. Et dans la pratique, si les historiens allemands, au début de leur carrière, cultivent l'un et l'autre domaines, ils ont toutefois tendance à se spécialiser par la suite, en histoire grecque ou en histoire romaine. Si l'on considère le cas de W. Nippel, il a commencé ses travaux avec une question "moderne " - celle de la constitution mixte -, qui interrogeait à la fois le monde grec et le monde romain ${ }^{4}$. Nous sommes là dans un autre type d'approche : l'histoire n'est pas affaire de domaines, de périodes ou de territoires, mais de questions, de problématiques.

Wilfried Nippel : But, in this case, I think I was rather an exception... I mean only from a statistical point of view!

Iwo Slobodzianek : Précisément, le dernier commentaire me fait penser à Max Weber, que vous avez beaucoup étudié, à cette manière de travailler à partir d'items, d'idéaux-types (la démocratie, la cité...). Diriez-vous que votre démarche - je pense en particulier à votre dernier ouvrage ${ }^{5}-s^{\prime}$ inscrit dans la continuité de celle de Weber ?

Wilfried Nippel : There is this famous saying: "On the shoulders of giants, even dwarfs can look further. "In my case, there is perhaps one significant influence of Weber on my Habilitationsschrift with some theoretical questions that at least go back to him

W. NipPel (dir.), Die späte Römische Republik - La fin de la République romaine : un débat franco-allemand d'histoire et d'historiographie, Rome, École française de Rome, 1997, p. 5-43.

4 W. NippeL, Mischverfassungstheorie und Verfassungsrealität in Antike und früher Neuzeit, Stuttgart, Klett-Cotta, 1980 (Diss.).

5 W. Nippel, Antike oder moderne Freiheit: die Begründung der Demokratie in Athen und in der Neuzeit, Frankfurt am Main, Fischer Taschenbuch Verlag, 2007, trad. O. Mannoni, Liberté antique, liberté moderne. Les fondements de la démocratie de l'Antiquité à nos jours, Toulouse, Presses Universitaires du Mirail, 2010. 
(the monopoly of legitimate violence, the different methods to secure public order without necessarily relying on a salaried staff of police, etc.). Another aspect: there's no unity in my work, but a certain diversity. I became interested in Weber as someone who looked for inspiration for his own work. But then I was asked to edit the piece on the city ${ }^{6}$ - which after all is predominantly dedicated to the medieval world -, and so I became interested in Weber as a towering-figure of late $19^{\text {th }}$ and early $20^{\text {th }}$ century scholarship, who isn't specialized but combines a number of different approaches and disciplines. I had been a member of the German Historical Institute in London in 1980/81 during the directorship of Wolfgang Mommsen and he offered me to do this edition more than a decade later. Wolfgang Mommsen was the key-person for the great Weber-edition ${ }^{7}$. He was the man who in the late 1950s recreated a new interest in Weber, but he stirred up the academic mandarins, since in a sense he related Weber's political ideas to the ideology of national-socialism. Mommsen has published widely on various aspects of the $19^{\text {th }}$ and $20^{\text {th }}$ centuries. But some people said he had done this work without really having made use of Max Weber; the same is also said about the famous Bielefeld historians Hans-Ulrich Wehler and Jürgen Kocka. They declared Max Weber a sort of standard-bearer of historische Sozialwissenschaft. Weber represented an alternative to a Marxist approach in ideological and methodological terms.

Anthony Andurand : Pour rester à la rubrique des influences intellectuelles, quand on parcourt vos travaux, trois noms reviennent fréquemment et semblent avoir joué un rôle important dans l'élaboration de votre démarche, tantôt comme interlocuteurs privilégiés, dans le dialogue ou la confrontation critique, tantôt comme sources d'une réflexion historiographique. Il s'agit de Max Weber, que nous venons d'évoquer, mais aussi de Moses Finley et Christian Meier. Quel a été l'apport respectif de chacun de ces savants dans la construction de votre propre démarche, à la fois comme historien de l'Antiquité et comme historien de la réception de l'Antiquité ?

Wilfried Nippel : Of course, one has to differentiate... Christian Meier was my academic teacher and my mentor throughout my early career. Without Meier, I would never had turned to Antiquity. I had no idea of the ancient world and just wanted to read history. Well, in a sense, it has never changed... What is the difference between doing history on the Roman Republic or on the $19^{\text {th }}$ century? In technical terms, of course, there are differences but all in all, I see no difference. When I took on the chair at Humboldt-University in 1992, I was interviewed by a student who ran a student paper and is nowadays working for Die Zeit. He asked me: "What is your

6 M. Weber, Wirtschaft und Gesellschaft, Teilband 5: "Die Stadt " (Max Weber Gesamtausgabe Band I/22-5), W. Nippel (Hg.), Tübingen, Mohr Siebeck Verlag, 1999.

7 H. Baier, M. Rainer Lepsius, W. Mommsen, W. Schluchter (Hg.), Max-WeberGesamtausgabe, Tübingen, Mohr-Siebeck Verlag, 1984-2011 (en cours), 41 vol. 
special love for Antiquity?" And I replied: "What? Consider I would be a historian of the Holocaust, of the Gulag, of the First or Second World War, would you have asked me what is my special love for the subject?" I try to remember a quote from, I think, Ernst Badian: "Someone who has fully understood the working of the Roman comitia centuriata, will have no problem at all to cope with every institutional or constitutional system in the world." And I think that's right!

So, it was just a biographical accident that I met C. Meier and that he promoted me. Then I started my doctoral dissertation. It was my idea to do a piece on the "mixed constitution", and of course I was thinking of doing it in ancient history. Polybius was the obvious case, but then I also tried to combine it with an approach related to constitutional history in Antiquity. And then I just came across that there was a long tradition, at least until the transformation of this concept within the American revolution (into a system of checks and balances), and detected the very interesting story of this concept within the English revolution. And Meier, with greatest liberality, let me carry on.

I don't believe that any traditional ancient historian would have awoken my interest in ancient history. Of course, Meier was interested in figures like Weber, but perhaps even more in Carl Schmitt: that has also fostered my interest in Carl Schmitt. I did later some smaller pieces on $\mathrm{Schmitt}^{8}$ - in a sense, probably also as a sort of opposition to the great teacher: one has to emancipate from a towering-figure at a certain time in one's intellectual development...

As for Moses Finley, I met him in 1981. I had been a year with W. Mommsen at the German Historical Institute London and then made contact with Finley. C. Meier obtained a grant for me so that I could carry on my Habilitationsschrift in Cambridge. There I have completed the first draft of Aufrubr und "Polizei". What was Finley's influence? Not so much on this particular subject but it was rather the impact of his personality, his openness for and immense knowledge of so many subjects. Afterwards, I regretted that at that time I was not well-informed on the history of scholarship and that I didn't ask Finley the questions I would have put ten years later, especially on his early career. I remember I tried to do it sometimes, but got the impression that he didn't want to discuss it.

Finley is also one these persons that stimulated my interest in Weber: the debate on ancient economy continued, and especially in Italy and France many scholars followed Finley's views on Weber. H. Bruhns opened my eyes on this aspect. He used to say: "All those French scholars quote Weber, but they only know what Finley has said about him." There was also a rather touchy situation: my first article on Max Weber was due to the fact that Finley had been invited to write a contribution for the

8 W. NipPeL, "Krieg als Erscheinungsform der Feindschaft ", in R. MeHring (Hg.), Carl Schmitt, Der Begriff des Politischen. Ein kooperativer Kommentar, Berlin, Akademie-Verlag, 2003, p. 61-70. 
International Congress of History in Stuttgart in 1985. He had submitted his paper, but ten or fourteen days before the conference I had a phone call from Finley: he said that he was unable to come to Stuttgart (I think it was due to health problems of his wife) and that I should present his paper. Of course, I was proud, but I was also in a great difficulty. I tried to present the paper, but also wanted to indicate that I would not subscribe to that! Normally, diplomacy is not my greatest virtue, but in this case, I think I did it quite well.

Hinnerk Bruhns : Je peux peut-être ajouter un commentaire en ce qui concerne C. Meier. Vu de France, C. Meier est un des grands historiens de l'Antiquité en Allemagne. En Allemagne, il a eu pendant très longtemps, dans la corporation des antiquisants, une position très marginale - il s'en moquait d'ailleurs.

Corinne Bonnet : Pour quelles raisons?

Hinnerk Bruhns : Il introduisait des théories (Weber et autres) dans la pratique de l'histoire ancienne, et ce n'était pas vraiment ce qu'il fallait faire à ce moment. Ce n'était pas quelqu'un - pour prendre un exemple français - comme C. Nicolet, qui organisait des séminaires et avait autour de lui toute une équipe. La plupart des très rares doctorants de Meier étaient des gens qui venaient d'ailleurs (de la science politique notamment) ou étaient, comme W. Nippel ou moi-même, attirés par sa personnalité, par tout ce qu'il faisait - je n'aurais moi-même pas fait d'histoire ancienne si je ne l'avais pas connu. Intellectuellement, Meier, dans les années 1970-1980, discutait avec des modernistes, des sociologues ou politologues, des philosophes, mais beaucoup plus rarement avec ses confrères, titulaires de chaires d'histoire ancienne.

Wilfried Nippel : In this sense, I am a sort of "mini-Meier" ! It's just the same: I like to call myself "the ancient historian for the others".

Hinnerk Bruhns : Quand Meier a été élu président de l'association des historiens allemands, ce ne fut pas grâce aux voix des antiquisants...

Wilfried Nippel : I am invited by modern historians, political scientists, etc., and they of course appreciate that I am interested in their subjects. It's only in my more major years that I think there should be a bit more of reciprocity. They always say: "Well, tell us how it was in antiquity and what we can do with it." But they don't want to be bothered with the shakiness of interpretations, questions of source-criticism, etc.

Corinne Bonnet : Et qu'en est-il de Momigliano?

Wilfried Nippel : Interesting again! I met him in London in 1981 thanks to Sally C. Humphreys. I had almost no idea of his work. He was an interesting, but 
also a somewhat bizarre figure. When he died, W. Mommsen - who was a member of the board of Storia della Storiografia - asked me to write an obituary ${ }^{9}$. I think it was the first time that I read greater portions of Momigliano's work. By chance again, in the 1990s, I came across Gibbon - one of the greatest subjects I've ever studied since then ${ }^{10}$. I realized the great potential of Momigliano's distinction between the antiquarian and the historical approach ${ }^{11}$, not only with respect to Gibbon but also $19^{\text {th }}$ century scholarship. Later, I was asked to co-edit a selection of Momigliano's papers in German ${ }^{12}$. The more I became acquainted with the history of scholarship, the more I admired Momigliano's work and the greater was my regret that he had never been able to write a good book on the subject - or more precisely two books: one on the history of early modern scholarship on antiquity, in all aspects, from Renaissance to the Enlightenment; another one on modern historiography since the $19^{\text {th }}$ century.

Iwo Slobodzianek : Nous avons parlé jusqu'à présent des influences ou des apports intellectuels. Je voudrais vous poser une question concernant, au contraire, vos repoussoirs, vos antimodèles, ou bien encore les réticences que votre démarche, volontiers transversale et parfois située à la croisée de plusieurs périodes et de plusieurs domaines, a pu susciter. Votre dernier ouvrage, de ce point de vue, a-t-il parfois rencontré des critiques auprès d'une partie des spécialistes, attachés à leur discipline et à leur territoire propres ?

9 W. Nippel, "Arnaldo Momigliano (1907-1987)", Storia della Storiografia, 14 (1988), p. 3-7.

10 W. Nippel, "Gibbons "philosophische Geschichte" und die schottische Aufklärung ", in W. Küttler, J. Rüsen, E. Schulin (Hg.), Geschichtsdiskurs, Band 2, Frankfurt am Main, Fischer Taschenbuch Verlag, 1994, p. 219-228 ; "Der Begründer der modernen Althistorie : Edward Gibbon ", in H. W. BLANKe et al. (Hg.), Dimensionen der Historik. Geschichtstheorie, Wissenschaftsgeschichte und Geschichtskultur heute, Köln, Böhlau, 1998, p. 209-220 ; "Gibbon and German Historiography », in B. Stuchtey, P. Wende (Hg.), British and German Historiography, 1750-1950. Traditions, Perceptions, and Transfers, Oxford, Oxford University Press, 2000, p. 67-81 ; " Edward Gibbon : "The History of the Decline and Fall of the Roman Empire" ", in E. Stein-HöLKeSKAmp, K.J. HölKesKamp (Hg.), Erinnerungsorte der Antike. Die römische Welt, München, Beck, 2006, p. 644-659 et p. 777-779.

11 W. Nippel, "New Paths of Antiquarianism in the Nineteenth and Early Twentieth Centuries : Theodor Mommsen and Max Weber", in P. N. Miller (Hg.), Momigliano and Antiquarianism. Foundations of the modern cultural sciences, Toronto, University of Toronto Press, 2007, p. 207-228.

12 A. Momigliano, Ausgewählte Schriften, Band 1 : "Die Alte Welt ", W. Nippel (Hg.), Stuttgart, Weimar, J. B. Metzler, 1998. 
Wilfried Nippel : Not really... There's one experience H. Bruhns has already mentioned with respect to C. Meier: there are those colleagues of mine who say that isn't really the work of an ancient historian. No problem!

As for other fields, when I write on subjects in relation to the English, American or French Revolution or German constitutional history I do very hard work, and in most cases go really to the main sources and do a lot of secondary reading. Of course, I can overlook something, but the decisive criticism would be: "He made a number of mistakes, but all in all, for an ancient historian, it's not that bad!" That would be a bad blow for me! But I have always avoided such criticisms - I hope - rather successfully. Of course, I have annoyed people with the book on Droysen ${ }^{13} \ldots$ Should I carry on with this one?

\section{Corinne Bonnet : Bien sûr!}

Wilfried Nippel : First of all, I did this book within a very short time - 15 months from signing the contract to submitting the text. I had never planned to write a book on Droysen. It was just a publishing house (Beck) that asked me to write it on the occasion of Droysen's $200^{\text {th }}$ birthday. They took the decision very late and obviously no serious scholar was available to write this book within such a short time!

It's a work with a special focus on $19^{\text {th }}$ century German politics and academic politics. I think one can also read it as a story (or even satire) on professors who overrated themselves - I mean this type of $19^{\text {th }}$ century political professor who thinks that he really can direct the way of politics. There were angry reactions, due to my playingdown of the importance of Droysen's Historik. My argumentation was: firstly, the success of the Historik is a posthumous one and can be explained with some strategic issues in the relationship between natural and cultural sciences; secondly, the Historik is a sort of justification for Droysen's own partisan approach to history. The third point was: why do they always praise the Historik? There is no other piece by a German professor - at least a published one - on the theory of history in the $19^{\text {th }}$ century. There were angry reactions, but some more private communications ran according to the motto: "I remember, in my earlier days, as a graduate student, we read this text with great admiration..." That was the reactions I had expected.

But I think the greater "insult" came from another aspect. One can also read that book as a lesson in source-criticism for all those German scholars who have published on Droysen by taking biographical details from the article of Otto Hintze ${ }^{14}$, which is not reliable at all as could have been known if someone had taken the trouble to

13 W. NippeL, Johann Gustav Droysen. Ein Leben zwischen Wissenschaft und Politik, München, Beck, 2008.

14 O. Hintze, "Droysen, Johann Gustav », in Allgemeine Deutsche Biographie, Band 48, Leipzig, Duncker \& Humblot, 1904, p. 82-114. 
check Hintze's sources. And nobody has analyzed Droysen's editorial policy, especially the publication strategy of his minutes from the Frankfort National Assembly in 1848. There was an edition of Droysen's political papers by Felix Gilbert in $1931^{15}$. It included a selection of 16 or 18 (anonymously published) newspaper articles by Droysen; but Gilbert presented also a list of 4 or 5 dozen of further articles by Droysen. There are at least 5 or 6 books on Droysen and the German-Prussian question. But apparently nobody has read those articles which were not published in the Gilbert collection. I have not read all but a great number of them. But in most cases, this point was passed with silence.

Corinne Bonnet : J'aurais une question qui concerne vos projets, vos travaux actuels. Parce qu'au fond le livre sur la liberté est un ouvrage qui a déjà deux ou trois ans, que vous avez sans doute rédigé en 2007. Que faites-vous depuis ? Sur quoi travaillez-vous?

Wilfried Nippel : Well, obviously, I have never been able to have a plan of my work. For example, this book, which is now presented in France, was started ten years ago. I often didn't know how to finish it. There was the problem of time-structure: how to relate contemporary and ancient debates? How to interconnect the discourses in constitutional history, rhetoric, politics, history of classical scholarship? I didn't know whether I would complete it at all. Someday it worked, and I finished the book.

Then there was this piece on Droysen. The book on liberty was finished before the Droysen-book, but the publisher - Fischer Taschenbuchverlag - had given up any hope: there was no place in their actual program and publication had to wait a while. In the meantime, I wrote the Droysen-book and Beck was eager to publish it some months before the $200^{\text {th }}$ birthday. The other one appeared a couple of months later.

Am I the person who really should say what I shall do in the future? To add more corpses to the cemetery of my unwritten books? Perhaps, I could mention one project. I'm now interested in dictatorship. It should be a sort of equivalent to the liberty book: to start from the Roman case, and then to reconstruct the debate on emergency measures and institutions in relation to the Roman case, which at least until the French Revolution was the crucial point of reference for dictatorship. It's interesting to see that, in a sense, the subject is now revived: I mean the American debate since "nine-eleven". Political scientists and lawyers say : "We need constitutional rules for emergency matters; if we continue to avoid them, it will all be the business of the president, who just says it's a matter of his presidential prerogative." And so, in a sense, the Roman model has a certain actual importance.

15 J. G. Droysen, Politische Schriften, F. Gilbert (Hg.), München, Oldenbourg Verlag, 1933. 
Another thing - should we put it off the record? - would be a book on Karl Marx, but not on Marx and Antiquity. I think Marx is one of the greatest journalists of the $19^{\text {th }}$ century. I mean his comments on politics in Germany, France, Great-Britain (with respect to India) and all those polemics with his enemies but also his comrades: that's really interesting stuff. And of course he had a plan of what he would like to write, but in most cases he was not able to do that, since he always reacted to challenges - not only political developments and personal quarrels but books and articles he had to criticize. That's why, in a sense, he never completed his great work on economics.

Corinne Bonnet : Y a-t-il encore en Allemagne des historiens qui se réclament du marxisme?

Wilfried Nippel : They have never done that! At least in West Germany...

Hinnerk Bruhns : Quant à Marx, je me dois de contredire mon camarade ! L'école de Bielefeld - l'histoire comme historische Sozialwissenschaft - affichait sur son drapeau quatre personnalités : Marx, Schmoller, Hintze, Weber. C'est-à-dire quatre références théoriques auxquelles on se reportait réellement dans la pratique et qui, en même temps, devaient conférer à cette nouvelle façon de faire de l'histoire sociale une légitimité scientifique : Gustav Schmoller et Otto Hintze furent invoqués au titre de l'histoire traditionnelle et reconnue, Max Weber au titre de la sociologie, disciplinephare dans l'Allemagne des années 1960 et 1970 ; ces trois contrebalancèrent en quelque sorte le recours à Karl Marx, dont on ne pouvait se passer dans une histoire sociale et dont l'évocation, dans la situation de la division réelle et idéologique de l'Allemagne, déclenchait des réactions très divergentes dans l'université allemande.

Wilfried Nippel : I mean in comparison with France or Italy, or with a small minority of British scholars (the group around Past and Present). In West-German universities, there was almost nobody amongst established historians who would have called himself a Marxist, as so many historians and classicists in France or in Italy proudly did.

Corinne Bonnet : Et que reste-t-il aujourd'hui de l'historiographie marxiste de l'ex-RDA ?

Wilfried Nippel : For me, it's now very interesting... Of course, it's often really dire... But one should not read the prefaces with the obligatory references to Marx, Engels, Lenin, one should not give up reading if every democratic movement or any democrat of the $19^{\text {th }}$ century is disqualified as "petit-bourgeois". There is a lot of scholarship that is very useful as source-publication. For example about the French Revolution: I think Walter Markov, who has done a lot of collaborative work with 
Albert Soboul (for instance on the movement of the sans-culottes ${ }^{16}$ ), is one of the greatest scholars on the French Revolution on an international level. Other people have done great work on the German Jacobines. When writing the book on Droysen, I came across a number of very useful publications on political parties, etc. In a sense, one can use DDR-scholarship from an "antiquarian" point of view as treasuries of sources. That applies also to East-German scholarship on Antiquity. Of course, a great number of publications are just without sense nowadays : I mean all those attempts to apply "the modes of production"-schema, such a useless expenditure of energy and even of paper on such a subject. But one has to accept, on the other hand, that all these theories and debates referring to Marx's scattered remarks on Antiquity were a sort of "lifeinsurance" for the scholarship on classical Antiquity.

Hinnerk Bruhns : Avant de poser quelques questions à W. Nippel, j'aimerais revenir sur la façon dont nous nous sommes rencontrés et avons commencé à travailler ensemble. Nous étions tous les deux assistants de Christian Meier dans les années 1970 à Bochum - j’y étais moi-même de 1976 à 1979. Nous partagions un grand bureau à l'université. Christian Meier était rarement là - il n'habitait pas à Bochum - et nous avions toute liberté. Je suis ensuite parti en France et c'est seulement par la suite que nous avons, en certaines occasions, publié ensemble, sur Weber et Finley, sur Weber et la ville, etc. ${ }^{17}$. Voilà pour la partie biographique.

J'aimerais revenir maintenant sur une question que nous n'avons fait qu'effleurer jusqu'à présent, une question qui concerne la dimension institutionnelle et l'exercice de notre métier d'historien de l'Antiquité. Quand vous êtes arrivé, en 1992, à Berlin, comme professeur à l'université Humboldt, c'était juste après la réunification. Il faut rappeler qu'à l'époque, l'intégration du système universitaire est-allemand dans le système universitaire de la République fédérale avait été organisé comme un processus d'Abwicklung, d' "évaluation ", et la vision générale était que les professeurs et les institutions de l'Ouest jugeaient la qualité de la recherche et de l'enseignement à l'Est, et que les postes les plus intéressants étaient réservés aux jeunes professeurs de l'Ouest. Quelle a été votre expérience de professeur de l'Ouest arrivant dans une université de l'ex-RDA, à la fois avec l'histoire telle qu'elle avait été enseignée auparavant dans cette partie de l'Allemagne, avec les étudiants, avec les collègues déjà en poste, à l'académie ou à l'université ? Comment cela s'est-il passé ? Fut-ce une époque difficile ou intéressante?

16 W. Markov, A. Soboul, Die Sansculotten von Paris. Dokumente zur Geschichte der Volksbewegung, 1793-1794, Berlin, Akademie-Verlag, 1957.

17 H. Brunns, W. Nippel (Hg.), Max Weber und die Stadt im Kulturvergleich, Göttingen, Vandenhoeck \& Ruprecht, 2000 ; H. Brunns, W. Nippel, « Max Weber, Moses I. Finley et le concept de "cité antique" ", OPUS, International Journal for Social \& Economic History of Antiquity, 6-8 (1987-1989), 1991, p. 27-50. 
Wilfried Nippel : That's right: interesting and difficult! I might correct you on one point. It was not the case that only Western professors did the evaluation of their Eastern colleagues. In the university there were mixed bodies. But politically, you're right, since the Eastern members had neither the experience nor the personal connections to counterbalance the Western group. There were actually three "camps": the newly-appointed Western professors and the Western experts who did the evaluation of institutions like the Academy; the Eastern incumbents who did not know what would happen to them; and there was a "third party", the East-Germans who had made the experience of being oppressed by their loyal to the line colleagues in the higher ranks.

A number of Eastern colleagues - those who were in office - felt of course as the losers of the process of reunification, but also a number of the other group of Eastern colleagues, since they had not the same sort of academic socialization as their younger Western colleagues. They were not used to accept, for example, that an application for a grant might be unsuccessful without implying a final verdict with respect to their future. They had the impression not to be accepted by the academic community. I often told them: "I've got a chair here at Humboldt-University, but between my first professorship in Bielefeld in 1983 and this one there were 9 years, and on several occasions I applied to a chair and didn't get it." But they had grown up in a system in which a graduate student (in smaller disciplines) might be told: "Complete your $\mathrm{PhD}$ and after that you'll be appointed for life. In fifteen years or so, the present professor will retire and you'll become his successor." Secondly - to come back to the last group -, there were also some people who said: "Functionaries had prevented me from making my career. If I would have been able to work freely, I would have published this book and another one; and now, assume that I have published these books and just appoint me to the post I really deserve." But to demand a sort of reparation by a bureaucratic act could not work.

The other problem was the almost total ignorance of the East German system. There were a number of Western experts, especially those in charge of the future of the Academy, which had employed a great number of scholars. West German professors followed the myth that Academy meant true scholarship and university only the fabrication of ideology and functionaries. They were wrong. In most cases, they were friendly with younger scholars, especially at the Academy, but in fact they had no sufficient knowledge of persons and institutions. Established scholars of East Germany had personal contacts with Western experts, and these contacts had increased since the mid-80s. And some of the Western experts said: "Well, of course, there were some communist phrases, but they have only paid lip-service to the ideology and all in all it's sober work..." But there were other people who said: "Maybe he's a scholar, but I tell you what he has done to me." I think that was a situation in which one could only make mistakes. But the question was: how many and on which side? There was a very rigid policy in Berlin with respect to Humboldt-University. Everybody had to apply for a new post, whereas in other East German Länder, there were other methods: in Halle, 
Leipzig, etc., a greater number of scholars could carry on teaching. A "good" situation was that a great number of the concerned professors were already about 60 years old, and so there were possibilities to employ them for five years or so.

For me, the greatest disappointment came from the comparatively younger East German scholars. There was this huge project with grants for them, so they had five years or so to work, for example, on their Habilitationsschrift. After only half a year (I came to Humboldt-University in April 1992), I took over the post of director of the Institute of History. We had all in all - in history - about 30 people, most of them came from former institutes of the Academy. I can't remember exactly but I think only 3 or 5 of them could use this chance. And that was due to this lack of academic socialization: they couldn't accommodate with a situation in which they would have to wait several years before being appointed.

The decisive point was time-pressure. For example, the treaty between the two German states (Einigungsvertrag) had set an absurdly short time-limit for the transformation of the Academy. In the meantime, at Humboldt-University, there was the great problem of the continuation of teaching. My idea would have been: "We close the university for two years and then we'll start anew, with new ideas and new structures." But we just had to carry on as we had done before. In the process of reunification, we transferred the West German system - that did not work well - on the Eastern side, since we had no time. That was also due to the fact that West-Berlin government was under strong pressure. They appointed all those new professors at Humboldt-University especially in "ideologically contaminated" disciplines like history, social sciences, jurisprudence, etc. There was also "friendly fire" from West Berlin. Freie Universität (FU) had been founded in 1948 as a "refugee place" and an outpost of the Free West. The idea was that after a future reunification there would already be a university. And now, West-Berlin government decided to reorganize Humboldt-University! So there was no chance for us to close it down for a certain period, or to form a sort of "eliteuniversity", since colleagues of the Fu said: "We don't like that at all. But if they do it, they should of course share the burden with great numbers of students."

As for students, I think that was a greater success story, for different reasons. First of all, there was a group of students who had organized protests against the East German system during the last phase of the régime. It was a small one since all members of universities were in a sense a privileged class. Students who had organized protests were now disappointed: "We had wanted to reorganize Humboldt-University from within!" But they were still used to study 4 or 5 years, and not, as their Western counterparts, to carry on indefinitely. There were almost no "student-functionaries", who were enrolled during 10 years or so and whose main occupation was to be a student member of academic bodies. Secondly, Humboldt-University suddenly became a very attractive place for students from all over Germany, as the Fu had been before. A great number of students from the FU and from all parts of Germany moved to us. After two years or so, I couldn't really tell you whether they came from East Germany or not except, of course, if they spoke in the famous dialect of Saxony or if I was addressed, in 
a letter, as "Werter Herr Professor". All in all, I think if there is a success story, then it's with respect to the students. "The wall in the minds", to use an often quoted phrase, disappeared quickly within the student population.

Hinnerk Bruhns : Une autre question. Nous avons parlé de la liberté que vous prenez à "braconner " dans d'autres domaines - par exemple lorsque vous quittez l'histoire ancienne pour étudier l'Angleterre ou le XIX ${ }^{\mathrm{e}}$ siècle. En même temps, vous êtes responsable d'un institut d'histoire ancienne, vous avez des étudiants à former : comment concevez-vous cette formation, par rapport à vos intérêts, qui ne sont pas toujours focalisés sur l'histoire ancienne ? Recommandez-vous à vos étudiants de devenir de solides historiens de l'Antiquité, " traditionnels " ? Les encouragez-vous au contraire à braconner ailleurs?

Wilfried Nippel : All in all, I must admit I'm a failure in educating young scholars. I always recommend: "Do serious, solid work in one discipline (in ancient history); don't commit the folly of starting with interdisciplinary work!" The result is: those who follow this recommendation opt for another patron. There were a number of younger scholars who were attracted by my work, but then, for example, started their doctoral dissertation with a modern historian. I have a very small number of Doktoranden or people who have completed their $\mathrm{PhD}$ with me. I've never recommended people to do it my way: I know how lucky I was; I know the amount of patronage that was necessary to appoint me at Bielefeld. And after that, I was quite happy, I could have continued there. I felt totally free to do what I liked to do, but I couldn't tell younger people it was a promising way. The result is that I have very few pupils in a technical sense - but in addition a certain number of "illegitimate" pupils.

Anthony Andurand : Je souhaiterais maintenant aborder avec vous le dossier des rapports entre l'histoire ancienne et l'anthropologie. On a longuement discuté, en France et ailleurs, particulièrement depuis les années 1960, sur ce qu'était ou pouvait être une " anthropologie de l'Antiquité " ou, plus largement, une " anthropologie historique ». Ces concepts recouvrent une pluralité d'approches, de discours, de pratiques. Quel a été l'écho de ce débat en Allemagne ? Quel sens, par ailleurs, donnez-vous vous-même à ces concepts? Dans quelle mesure seraient-ils susceptibles de s'appliquer à vos propres travaux?

Wilfried Nippel : First of all, it's one of those things that grew out of a certain challenge. One of the first reviews I did was on S. Humphreys' collection of essays ${ }^{18}$. I wrote a few pages for the Historische Zeitschrift - they of course said it was too long.

18 W. Nippel, "S. C. Humphreys, Anthropology and the Greeks, London, 1978 (Rezension)", Historische Zeitschrift, 232 (1981), p. 390-393. 
I had the idea to expand it and the article was published in Chiron $^{19}$. It was one of the very few cases in which I made a conscious strategically-minded decision in view of my future career by publishing it in a scholarly journal on ancient history. If I had published it in History of Anthropology, for instance, ancient historians would have said: "We know this guy; he has no interest in ancient history, and we are not interested in anthropology." And if I have a virtue, it's curiosity. I didn't know all this stuff, I started to read it and try to put it together. The result was the booklet on Griechen und Barbaren $^{20}$. But for me, personally, it was a dead-end, for various reasons. I was interested in intellectual history, excited to see how great scholars of the $19^{\text {th }}$ century like L. H. Morgan, H. S. Maine, Marx studied kinship systems and the law of land-tenure in India and elsewhere and compared them to Roman or old Germanic structures or to the Russian mir, etc. And I sometimes thought it could perhaps have an impact on ancient history. That I did not carry on is due to my lack of expertise for questions of religion, kinship systems, etc., and to my own preference for political, intellectual and cultural history. If I would try to justify my intellectual narrowness, I would quote Jacob Burckhardt: "You should start everywhere with the beginnings, except in history." So, all in all, it was an interesting experience for me, but it had no real impact on my later work on Antiquity. I should better never have said: "You or we should do it this way." With a certain maturity, I think: "No programmatic announcement! The only one who has to stand comparison with such a proclamation will be yourself and you'll fail!"

Hinnerk Bruhns : J'ai relu, récemment, l'article en question. Quand on regarde votre façon d'écrire de l'histoire, ce qui frappe par rapport à beaucoup d'autres, surtout en France mais aussi en Allemagne, c'est une immunité totale contre les " modes " intellectuelles. En France, on dit toujours - Max Weber le regrettait déjà - que les historiens allemands commencent leur thèse par un long chapitre théorique. Ce n'est pas du tout votre façon de faire. Dans l'article en question, les références aux théories ne sont pas des éléments décoratifs ou une quête de légitimité. Au contraire, il s'agit de voir - c'est la question que vous posez - si leur application pratique, ici, au cas de la Grèce, est utile ou s'il faut modifier le modèle théorique.

Dans votre récent ouvrage sur Liberté antique, liberté moderne, en revanche, votre perspective sur la Grèce antique est, en quelque sorte, beaucoup plus resserrée : vous analysez la démocratie athénienne sous l'angle des procédures politiques et juridiques, vous vous intéressez à la technicité constitutionnelle. Par contre, vous ne posez pas

19 W. Nippel, «Die Heimkehr der Argonauten aus der Südsee. Ökonomische Anthropologie und die Theorie der griechischen Gesellschaft in klassischer Zeit ", Chiron, 12 (1982), p. 1-39.

20 W. Nippel, Griechen, Barbaren und "Wilde». Alte Geschichte und Sozialanthropologie, Frankfurt am Main, Fischer Taschenbuch Verlag, 1990. 
vraiment la question de savoir quelle a été, en dehors des aspects constitutionnels, des procédures et des jeux de pouvoir, la signification de la singularité de la démocratie athénienne du point de vue de l'histoire universelle et du point de vue d'une anthropologie historique et politique. Ces questions n'apparaissent pas non plus dans votre analyse si détaillée de la réception de la démocratie athénienne à l'époque moderne et contemporaine.

Je ne crois pas que cela tienne seulement à un manque d'expertise dans ce domaine. Cela tient aussi, je pense, à la situation allemande : à Bielefeld, à Berlin ou ailleurs, il n'y a pas - ou, en tous cas, il y a moins - ce qui caractérise la situation française, et non seulement parisienne, à savoir des réseaux, des groupes, des rencontres régulières entre historiens (de différentes périodes), anthropologues et spécialistes d'autres domaines intéressés par des questions d'anthropologie historique. Il n'y avait pas en Allemagne ce milieu où ces questions étaient sans cesse reformulées, et donc moins de sollicitations pour continuer dans cette direction.

Wilfried Nippel : And also a certain skepticism...

Anthony Andurand : Quel a été de ce point de vue l'accueil en Allemagne des travaux de Jean-Pierre Vernant ou de Pierre Vidal-Naquet, issus de l'anthropologie historique?

Wilfried Nippel : For me, a great number of these works represent a "strange" world - Vernant obviously more than Vidal-Naquet, who is more accessible to people like me. It's similar to my reading of the famous article of Clifford Geertz on the Balinese cock-fights ${ }^{21}$. It was fascinating, but then: what's the result for an "old-fashioned" historian like me? It's certainly unfair towards Vidal-Naquet or Vernant. But I think it's representing the great difficulty to overcome the great gaps between scholarly and cultural traditions that go back over decades and centuries.

Corinne Bonnet : Sont-ils traduits en allemand?

Wilfried Nippel : Vernant and Vidal-Naquet of course are translated into German $^{22}$. For example, I've only intellectual access to, say, 6 of the 12 articles the

21 C. Geertz, "Deep Play : Notes on the Balinese Cockfight ", in The Interpretation of Cultures, New York, Basic Books, 1973, p. 412-453.

22 J.-P. Vernant, Mythos und Gesellschaft im alten Griechenland, Frankfurt am Main, Suhrkamp, 1987 ; Die Entstehung des griechischen Denkens, Frankfurt am Main, Suhrkamp, 1991 ; Tod in den Augen : Figuren des Anderen im griechischen Altertum : Artemis und Gorgo, Frankfurt am Main, Fischer Taschenbuchverlag, 1988 ; Mythos und Religion im alten Griechenland, Frankfurt am Main, Campus, 1995 ; Der maskierte Dionysos. Stadtplanung und Geschlechterrollen in der griechischen Antike, Berlin, Wagenbach, 1996 ; 
Chasseur noir is composed of; the other ones are exotic to me. Interesting, but not in the sense I could use them.

Corinne Bonnet : Vous avez pourtant écrit l'entrée « anthropologie ${ }^{23}$ » dans le Neue Pauly...

Wilfried Nippel : I don't really remember... But you can use it as piece of evidence against me!

Pascal Payen : Mes questions porteront sur le domaine que les spécialistes nomment la réception de l'Antiquité. Pour les non-spécialistes, j'aime habituellement à configurer un peu autrement ce nouveau champ sous la forme d'une question : qu'advient-il de l'Antiquité après l'Antiquité ? La réception de l'Antiquité est un domaine en pleine évolution, au sein des sciences de l'Antiquité elles-mêmes et, plus largement peut-être, au sein de l'histoire et des sciences humaines. Nous savons tous que des colloques, des revues lui sont consacrés, de grandes collections lui font place, ce champ scientifique produit même de nos jours des textes théoriques et programmatiques : il n'est plus seulement l'apanage de quelques grandes figures - Momigliano, Finley, Vidal-Naquet plus récemment - qui se livraient aux études consacrées à la réception de l'Antiquité. Une part de plus en plus importante de vos recherches est consacrée à ces questions : je songe aux travaux que nous avons déjà évoqués, sur Weber, Droysen ou sur la démocratie athénienne. J'aimerais à ce sujet vous poser une première question : en quoi consiste selon vous la "modernité " de l'Antiquité ? Du moins pour notre temps présent, car je sais bien que cette question mérite d'être posée à tous les présents de l'histoire.

Wilfried Nippel : I've done a lot on the history of reception. But again, in a comparatively narrow field: I didn't do it in the realm of belles-lettres, architecture, etc. I prefer to concentrate more on subjects in which I have - I think - a certain competence rather than in fields in which I would start as a dilettante. But "modernity of Antiquity"? No, I don't think it's "modern". I could come back to one of my first answers. Why Antiquity? Why the Middle Ages? Why Renaissance? Why the early modern period? As Ranke has said: "Every epoch is equally near to god." I wouldn't

Zwischen Mythos und Politik, Berlin, Wagenbach, 1997. P. VIDAL-NAQUET : Der schwarze Jäger. Denkformen und Gesellschaftsformen in der griechischen Antike, Frankfurt am Main, Lang, 1989 ; Die Schlächter der Erinnerung : Essays über den Revisionismus, Wien, WUV-Universität-Verlag, 2002 ; Athen. Sparta. Atlantis. Die griechische Demokratie von außen gesehen I, München, Fink, 1993 ; Paris - Athen und zurück. Die griechische Demokratie von außen gesehen II, München, Fink, 1996 ; Atlantis. Geschichte eines Traums, München, Beck, 2006.

23 W. NippeL, «Anthropologie », in Der Neue Pauly, Bd. 1, Stuttgart, 1996, p. 740-744. 
say: "Antiquity has to teach us lessons for today." But of course its cultural impact - at least on the Western tradition - is greater than the one of other periods of history. The interesting point in the reception of Antiquity is that there is a reception of a reception of a reception... For me, that's fascinating. All in all, if someone says we should concentrate more on non-Western, non-European cultures, what could I reply? I can only say: "Of course it's very important from the aspect of universal history and we should try to take it into account. But only preserving our cultural heritage enables us to engage in inter-cultural exchanges." I wouldn't say Antiquity should have a privileged position in our canon of knowledge and disciplines, but in a sense an overproportionate one, with respect to its historical impact.

Pascal Payen : Une deuxième question. Les études de réception de l'Antiquité seraient-elles une voie pour renouveler l'étude de l'Antiquité classique ? Autrement dit, n'ont-elles leur place que dans ce domaine - l'Antiquité classique -, ou bien peuventelles se développer de façon autonome, au contact des sciences politiques par exemple, avec le risque, dans ce cas là, d'être coupées de leur substrat antique ?

Wilfried Nippel : The discipline would be lost if the only way to save ourselves would be to do reception history. One should be self-confident: with the arguments or reasons I mentioned before, we should do ancient history for itself, and then we'll see which effects it will have on the concert of disciplines. History of reception can play a significant role in this interaction between disciplines but it should always be based on serious knowledge of the ancient evidence and the respective scholarly works. As a younger man I started with those ideas of "one should do history with a theory in mind", but nowadays appreciate the great works of the $19^{\text {th }}$ century scholars, of these "hunters and gatherers" who collected every item and put them in manuals. It took a time for me to prefer sober - perhaps even dull - works that present mines of information. They are not out-dated: I can rely on their accurateness, can be sure that they have collected all relevant materials (apart from newly discovered sources, of course) and then I can form my own idea. But what should I do with someone who has followed the most recent intellectual mode and has selected his material according to preconceived ideas? I'm rather skeptical about those people climbing up the last intellectual wave. I don't like to read books with a long introduction on the only way to do history and then find the results not really exciting.

Pascal Payen : Une dernière question. Il nous arrive de plus en plus, dans nos universités, d'avoir à justifier la présence de nos enseignements. C'est vrai en France, c'est vrai en Allemagne et peut-être plus vrai encore dans un pays comme l'Italie. Que signifie pour vous faire de la recherche sur l'Antiquité dans l'université d'aujourd'hui? 
Wilfried Nippel : In Germany at present, I see no problem to justify our work on ancient history. There may have been a time, some years from 1968 onwards, when some people said history starts with the French Revolution or even better the Bolshevik Revolution. But then we had this great expansion of chairs for ancient history in the 1970s. I mean all these newly founded universities, and almost all of them have a professorship for ancient history. Of course, all those people were expected to teach both Greek and Roman history - but that's another subject we have already discussed. Nowadays, I think the situation in Germany is not the same as for example in Great-Britain. I mean all these questions of usefulness... We have a friendly climate towards Geisteswissenschaften. We have all those new collective research units (Sonderforschungsbereiche) or the strange "clusters of excellence", etc., and in all those interdisciplinary groups classicists and ancient historians are present. Of course, I could underline the poor situation of the universities, the lack of financial funds, the overload of teaching, etc. In Germany, since the late $19^{\text {th }}$ century, when classical studies lost their position as lead-discipline, they always said: "Now, it's over! The Untergang des Abendlandes is coming." There were all those debates on the Gymnasium, and the lamentation: "That's the end of our classical tradition"... Shortly, I see no greater problem for classical studies than for any other field of Geistes- und Sozialwissenschaften.

Hinnerk Bruhns : Sauf peut-être un fait : il y a de moins en moins d'étudiants qui savent le latin et le grec.

Wilfried Nippel : Of course. But as for Latin, it's not that bad. The number of pupils learning Latin is not really declining. Maybe it's a new trend to establish a "status-marker"...

Corinne Bonnet : Une question sur la religion. Vous avez dit que cela ne faisait pas partie de vos compétences. Vous avez pourtant publié un article sur le procès des Bacchanales ${ }^{24}$. Par ailleurs, dans votre dernier ouvrage, le facteur de liberté religieuse, de liberté de culte, est certes évoqué par moments, mais n'est pas du tout au centre du discours. Or, c'est une question dont les historiens des religions discutent beaucoup aujourd'hui : je pense au concept de "distinction mosaïque " de Jan Assmann ${ }^{25}$ l'idée que le polythéisme serait " tolérant » et le monothéisme "intolérant ». Avez-vous un avis sur la question de la liberté religieuse ? Comment s'articule-t-elle à la liberté politique?

24 W. Nippel, « Orgien, Ritualmorde und Verschwörung ? Die Bacchanalien-Prozesse des Jahres 186 v. Chr. ", in U. Manthe, J. von Ungern-STERnberg (Hg.), Große Prozesse der römischen Antike, München, Beck, 1997, p. 65-73 et p. 199-202.

25 J. Assmann, Moses der Ägypter. Entzifferung einer Gedächtnisspur, München, Carl Hanser, 1998, trad. Moïse l'Égyptien : un essai d'histoire de la mémoire, Paris, Flammarion, 2003

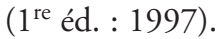


Wilfried Nippel : My article on the bacchanals was no piece on religious history. I was interested in how the Roman authorities dealt with a sort of conspiracy.

Obviously, you didn't notice that I did some pieces on early Christianity. That was an "influence" of Weber: his idea of "fraternization" (Verbrüderung), that took place in the community of Antioch between Jewish and pagan Christians, and the problem of the Eucharist there. Weber said that was the beginning of a new dimension in world history ${ }^{26}$. I was interested in that. I was also interested in the fate of Saint Paul ${ }^{27}$ : again, it was more on Roman legal questions of appellatio and provocatio, etc. And there was again a peculiar biographical factor. The first seminar I did on Saint Paul was in Berlin when I had to instruct East German teachers, who took supplementary courses to be appointed again or promoted to a higher rank. And I thought: "How can I provoke them?" The provocation was that I took a sort of holy text - not a holy text for most of them, but they were accustomed to authoritative interpretation of holy texts of a quite different sort - and said: "No matter that it is from the New Testament, just focus on the historical question; let's look what we can extract from this source by interpreting it as we do with all other texts." In a sense, it was a success. I did also some seminars on Judea under Roman rule and on the trial of Jesus, and one of the few doctoral dissertations I have supervised successfully was on the role of the Roman governor in Judea. All in all, it's not really religious history: it's always connected with constitutional history or penal law, etc.

I shrink from great theories with universal claim. For me, the decisive point of your question is related to the book on democracy. Can one write about the history of liberty without referring to Christian traditions? Put it this way, the answer is: "No". I can justify myself with the connection I made with the reception of Athenian democracy. Otherwise, if we come to human rights, there is the French-German debate of the late $19^{\text {th }}$ century: what is really the source of the idea of human rights? G. Jellinek ${ }^{28}$ said it goes back to dissenters in England and New England, and there's only one fundamental human right, and that is the liberty of conscience and faith: all other human rights are "derivations" from this one. The second point would be on

26 W. Nippel, "Verbrüderungen, Vereinigungen, christliche Gemeinde ", in H. Kaelble, J. SChriewer (Hg.), Gesellschaften im Vergleich : Forschungen aus Sozial- und Geschichtswissenschaften, Frankfurt am Main, Lang, 1998, p. 3-11.

27 W. NipPel, " Der Apostel Paulus - ein Jude als römischer Bürger ", in K. J. HöLKesKamp et al. (Hg.), Sinn (in) der Antike. Orientierungssysteme, Leitbilder und Wertkonzepte im Altertum, Mainz, Von Zabern, 2003, p. 357-374.

28 G. JellineK, Die Erklärung der Menschen- und Bürgerrechte. Ein Beitrag zur modernen Verfassungsgeschichte, Leipzig, Duncker \& Humblot, 1895 ; É. BouTMY. "La déclaration des droits de l'homme et du citoyen et M. Jellinek ", Annales des sciences politiques, 17 (1902), p. 415-443 ; G. JellineK, "La déclaration des droits de l'homme et du citoyen. Réponse de M. Jellinek à M. Boutmy ", Revue du droit public et de la science politique en France et à l'étranger, 18 (1902), p. 385-400. 
a more technical level. As for appointment to offices, methods of (secret) voting, etc. one should also look into the history of the Church and of diverse religious orders. For example: the two-third majority rule was invented for the election of the Pope in the late $12^{\text {th }}$ century. The very idea of representation in the sense of the legal responsibility of the representative who can vote without coming back to the actual opinion of those for whom he votes, is part of the Roman legal tradition (in private law) that then was taken over by Christian institutions. One could also construct a history of representation going back to the history of the Church and of the orders. These aspects are, up to now, not really recognized in the mainstream of political theory and of the history of political thought. But a comprehensive history of the idea of liberty would have to take these aspects into account. I remember a scholar who has done it in a certain way: that was the Momigliano of the $19^{\text {th }}$ century - he has written great articles, but no books -, I mean Lord Acton. Of course he was motivated by his personal situation as a catholic in England and as a friend of Döllinger, who due to his protest against Vatican's declaration of the Pope's infallibility was excommunicated and then became the leader of the Altkatholiken.

Hinnerk Bruhns : Pour laisser de côté votre domaine de prédilection et votre biographie personnelle, y a-t-il actuellement en Allemagne, en histoire ancienne, des questions ou des problématiques nouvelles, qui différencieraient l'approche allemande? Ou bien y a-t-il au contraire une homogénéisation des approches en Allemagne, en France, en Italie, en Angleterre ? Est-ce seulement un champ traditionnellement établi en Allemagne ou bien aussi un champ intéressant?

Wilfried Nippel : Difficult to answer... On the one hand, there seems to be a return to traditional topics, and - as I have said before - I'm not that unhappy about it. On the other hand, there are very ambitious projects and pronouncements; let us see how they will be fulfilled. With respect to England and America, I think they're getting more and more provincial, in the sense that they don't recognize anything that is not written in English. And even established academic presses are no longer prepared to accept that in books for the student market works in French, German or Italian are quoted.

But I should better stop here! I could also say I've lost contact during the last years doing other things. I'm now over 60 and excepted to present myself as a serious scholar!

Corinne Bonnet : J'aimerais vous interroger sur la tendance actuelle qui n'est pas propre à l'histoire ancienne mais à tous les domaines : la tendance à l'évaluation. Quel est votre avis sur toutes ces structures d'évaluation que nous devons subir : évaluation des publications, des instituts et des programmes de recherche, etc. ? Est-ce de nature à améliorer réellement nos travaux ? 
Wilfried Nippel : It's the usual way nowadays. But until now, it applies only for research projects for which grants are demanded. I could still do my work according to my particular interests, even if someone would write a negative report on me. The evaluation machine is running for all those research units and programs, clusters of excellence, syllabi. I'm very pleased that I'm now approaching the end of my career. I know from younger persons who are appointed to a professorship that they have a new salary structure; their salary depends partly on their success in raising funds - from the Deutsche Forschungsgemeinschaft (DFG) for instance - for research programs. That's really new, and I'm happy I don't have to bother about that.

All in all, my complaint about the system is that there is only evaluation of projects, but no evaluation of results. Consider someone like me, who is well-known - that means people have an opinion on me, whatsoever. If I had the idea of a great project - for instance about dictatorship -, I would say: "You know my work on liberty and democracy; I will now write the equivalent about dictatorship and need two research assistants or, better, a two-year leave from other duties." It would be that easy: I would write one page and they could say: "The first book was a success and obviously it's a field he's an expert in"; or: "we won't support the next disaster." If I happened to get the money, I would produce a book, hopefully. Afterwards, they could evaluate the result: "It was OK, and if you like to apply again, do it the same way next time", or "don't call on us for the next five years!" It would be that easy! The only point the university is interested in is that you get money for projects, but nobody asks for the results.

Corinne Bonnet : Une dernière question, anecdotique et un peu humoristique. Y a-t-il, dans l'Antiquité, une figure qui est pour vous une idole, un personnage que vous admirez?

Wilfried Nippel : Really, I have no idea. Admiration is not my business. Please, make an offer!

Corinne Bonnet : Quelle est votre opinion, par exemple, sur Périclès ? Est-ce un personnage pour lequel vous avez de l'admiration?

Wilfried Nippel : Of course, I would try to reconstruct the historical role, to see the positive and negative aspects, but I have no capacity to admire. I could, however, give the names of some great football players. They are not in a position to do really harm to a society. 